Sex Trafficking and Sex Tourism in a Globalised World

Professor Ann Brooks

Professor of Sociology

Department of Social Science and Social Work

Faculty of Health and Social Science, Bournemouth University

abrooks@bournemouth.ac.uk

Dr Vanessa Heaslip

Principal Academic Department \& Dept Head of Research of Nursing \& Clinical Science

Faculty of Health and Social Science, Bournemouth University

vheaslip@bournemouth.ac.uk 


\section{Sex Trafficking and Sex Tourism in a Globalised World}

\section{Abstract}

Purpose- This paper explores the dark side of the relationship between gender, mobility, migration and tourism. Specifically the paper looks at one form of human trafficking, the global sex industry and the relationship between sex trafficking and sex tourism. More particularly, the paper examines the global sex industry (Goh 2009; Sassen 2000, 2001); the impact of migration and human rights aspects (Voronova and Radjenovic 2016) of sex trafficking and sex tourism as well as the emotional dimensions of trauma, violence and vulnerability (Author B).

Design - The paper is an interdisciplinary discussion paper combining socio-economic perspectives (Goh 2009; Author A), human rights perspectives (Cheah 2006), migration perspectives (Voronova and Radjenovic 2016) tourism perspectives (Carolin et al 2015) and health perspectives (Cary et al. 2016, Matos et al. 2013, Reid and Jones 2011). The contribution of these intersecting perspectives to an understanding of sex trafficking and sex tourism is explored.

Findings - The paper highlights the moral and ethical responsibility of the tourist industry to counteract sex trafficking and sex tourism, an issue which tourism studies have failed to fully engage with. In presenting the human costs of trafficking from a gender perspective, the paper considers the ways in which the tourism industries, in some countries are attempting to respond.

Originality/Value - In theorising the relationship between gender, migration, sex trafficking and tourism from an interdisciplinary perspective, exploring the societal and individual impact, this paper provides a framework for further empirical research or policy changes with regards to the intersection of sex trafficking and tourism.

\section{Key words}

Sex trafficking, sex tourism, human rights, migration, vulnerability

\section{Introduction}

Tourism is of course a global industry. This paper considers the darker aspect of this industry which is sex tourism, parts of which have been fuelled by sex trafficking. As Carolin et al (2015:1) comment:

“... one of the ways the hospitality industry is involved in exploitation is through its conscious or unconscious participation in sex trafficking of men, women and children" (see Goh 2009; Sassen 2000, 2001). 
Whilst the term trafficking is commonly used, the United Nations Office on Drugs and Crime ((UNODC) 2009) argue that the term 'trafficking' is misleading due to the focus it places on the transaction rather than the human aspects of the crime arguing that 'enslavement' is more accurate. As such, human trafficking exploration and reporting falls under the umbrella of 'Modern Slavery'; a concept relating to specific legal situations relating to forced labour, debt bondage, forced marriage, slavery, slavery-like practices and human trafficking. Common to all of these experiences is exploitation, in that the individual has limited rights, they are unable to refuse or leave due to violence, coercion, and the abuse of power (International Labour Organisation 2017).

The most recent figures of Modern Slavery (International Labour Office 2017) identify that during 2016, 40.3 million people were victims of modern slavery. Of these, 24.9 million were forced into labour such as construction, agriculture, factories and of interest to this paper, the sex industry. Gender differences in Modern Slavery are also apparent in that it is more prevalent for women and girls, accounting for $71 \%$ or 28.7 million victims (Human Rights First 2017). However when it comes to forced labour in the commercial sex industry women and girls equate to $99 \%$ of victims, and of these $21 \%$ are children (Human Rights First 2017).

As we can see gender is a significant factor in global sex trafficking and has attracted interdisciplinary research and analysis (see below). There are a wide range of intersecting perspectives drawn on in this paper which contribute to an understanding of sex trafficking and tourism including socioeconomic perspectives (Author A, Author A; Goh 2009), human rights perspectives (Cheah 2006; United Nations 2000; UNHCR 2005), migration perspectives (Voronova and Radjenovic 2016), tourism perspectives (Carolin et al 2015) and health perspectives (Cary et al. 2016, Matos et al. 2013, Reid and Jones 2011). This paper examines the intersection of migration, sex trafficking and sex tourism and considers ways in which the tourism industry and different countries are responding to this issue.

\section{Statistics on Sex Trafficking}

Human trafficking includes trafficking for sexual activities and has been a long standing issue. A definition of sex trafficking includes: "the recruitment, harbouring, transportation, provision, or obtaining of a person for the purposes of a commercial sex act" (US Dept. of State 2012). Despite human trafficking being a long standing issue, there remains an absence of systematic research regarding true statistics on the total numbers of individuals being trafficked. Reasons for this are multi-faceted, including the extreme marginalisation and invisibility of the vulnerable individuals 
who are trafficked, the hidden, criminal yet highly profitable nature of trafficking as well as a lack of systematic anti-trafficking legislation (UNODC 2016).

Feminist theorist Jill Doezema (2010: 5) maintains that trafficking is a contested discursive terrain and that it is difficult to quantify trafficking. She cites a report by the International Organization for Migration (2000) which notes that trafficking is often confused with 'smuggling' or illegal migration. Additionally she cites a report on international trafficking by the Global Alliance Against Trafficking in Women (GAATW) who maintain that when statistics are available they tend to refer to the number of migrant or domestic sex workers as opposed to cases of trafficking (Lim and Wijers 1997). Doezema also makes the point that when statistics on trafficking are confused with "illegal migration" or "migrant prostitution" the problem is compounded by the compilation of figures by police and ministries of justice. As she points out some countries have no laws on trafficking whilst others do. Doezema (2010:7) does however assert that the numbers of migrant sex workers is increasing throughout the world (see Augustin 2008; Kempadoo 2005).

Noting the challenges regarding the statistics on sexual trafficking referenced above, Human Rights First (2017) estimates that of the $\mathbf{2 4 . 9}$ million victims trapped in modern-day slavery, 4.8 million (19\%) were sexually exploited. Furthermore UNODC (2017) argues that sexual exploitation accounts for $79 \%$ of human trafficking. Sex trafficking is defined as a severe form of trafficking as classified by the Trafficking Victims Protection Act (US Dept. of State 2012), it is also outlawed in the UK (Modern Slavery Act 2015). There is a clear gender difference in terms of males and females being lured into sex trafficking. Females are lured by pimps or someone they know, whereas males are often lured in as a result of being rejected by a family and their sexual preferences (Reid 2012). Sex trafficking does not only include adults but also children. The report 'Global Estimates of Modern Slavery' (International Labour Office 2017) identified that children equate to 21 per cent of the total victims of commercial sexual exploitation. Furthermore, the US Department of State estimate that over one million children are trafficked for sex throughout the world (Dept. of State 2006). Children between the ages of 14-17 in the US are the largest percentage sold for sex. In developing countries, poverty and gender inequality are key factors in the sale of women and children for sex trafficking.

Sex trafficking can be distinguished from sex work; in which consenting adults make an informed choice to engage in the provision of sexual services (such as pornography, exotic dancing, prostitution etc.) in exchange for payment. However, it has to be remembered that sex work can also be part of coercive trafficking, in that sex trafficking for profit can also include pornography, 
prostitution and sex shows (Reid 2012). The main difference is not in the sexual act performed but rather in the voluntary choice of an adult engaging with it. In other words sex trafficking is a coercive action and involves relationships of power, specifically, the abusive relationship of power, in which one person has 'power over' another individual, controlling their behaviour and actions (Ryden and Willets 2013). This control is endorsed through physical and emotional abuse and over time renders the vulnerable individual more helpless as they internalise the feelings of self-stigma and shame (see below).

While sex trafficking is not a new phenomenon, Voronova and Radjenovic (2016: 2) note that: "Human trafficking has acquired a new dimension in the context of globalisation and been facilitated by increased mobility, especially in Europe, and the development of the internet and new technologies... Even though collecting data on human trafficking is difficult because of its invisible nature, recent years have seen progress at both international and EU level, and extensive reports have been published by the United Nations Office on Drugs and Crime (UNODC) and Eurostat".

Within Europe, information collected by the European Commission (2012) identified similarities between the European and Worldwide picture of human trafficking in that around 76 per cent of individuals are trafficked for sexual exploitation. Information from 21 member states identified that women and girls are the likely target, accounting for 79 per cent of trafficked victims (12 per cent being girls) and the majority of individuals trafficked from the EU come from Romania, Bulgaria, Poland and Hungary.

\section{Globalization and Sex Trafficking}

While poverty is a key factor in sex trafficking in developing countries, it is also important to note that trafficking is also a feature of developed countries. For example, open borders in Europe have contributed to the development of trafficking; this has been recognised and led to the development of a European treaty affirming action against trafficking in Europe (Secretary of State 2012). Many countries with human rights and trafficking laws experience trafficking. The border between Mexico and the US has also been open to trafficking with Mexico being a country of origin for around 5,000 children and women being brought into the US every year (see Author A).

It is clear that sex trafficking is a global phenomenon and Goh (2009) outlines the relationship between sex trafficking and global cities including Dubai, Tokyo and New York. Goh (2009:271) 
argues that: "despite the proliferation of international institutions, conventions and agents united by a common agenda to combat trafficking, sex trafficking is still a growing transnational process." She agrees that sex trafficking is a form of modern day slavery which involves the transaction of women as sexual objects all over the world, and not just developing countries. Instead she perceives it as an transnational process, in which women are objectified and perceived as commodities to be bought and sold rather than as individual human beings with rights (Goh 2009:273).

However Doezema (2010) and Kempadoo (1999, 2005) present slightly different perspectives, Doezema (2010:8) maintains that the majority of trafficked women are made up of sex workers rather than "coerced innocents". The GAATW report which is largely based on organizations that work directly with trafficking victims found that the majority of women who are trafficked "involve women who know they are going to work in the sex industry" but the conditions they work under are not what they anticipated. In addition a range of global research: in Australia (Murray 1998), Saudi Arabia, Nepal, India (Blanchet 2002), England, Italy, Thailand and the US (Pearson 2002) and in Europe (Augustin 2005, 2006, 2008) indicate that women are not easily "duped" or "deceived" and are aware that they are going to work in the sex industry.

\section{Migration, Trafficking and Europe}

Whilst we may consider human trafficking as something that occurs across countries in the world, the evidence by the European Court of Auditors (2017) informs us that it largely occurs within the borders of individual countries (42\%) or regions (36\%). According to Eurostat, 65 percent of victims are EU citizens. Trafficking flows, facilitated by the absence of border controls within the Schengen area, are mostly from Eastern and Central Europe to Western Europe. However, Western Europe is the destination of choice for human trafficking from Asia, Africa and South America. In addition, Voronova and Radjenovic (2016:3) state that trafficking from Nigeria, predominantly women and girls for sexual exploitation is a regular and persistent channel to Europe. They also show that in the period 2010-2012, 53 per cent of victims in the world were trafficked for sexual exploitation and of those 97 percent were female. They continue that for the same period, the EU registered even higher figures for sexual exploitation showing 69 percent as victims, of whom 95 per cent were women and girls.

The data from Voronova and Radjenovic (2016) drawing on UNODC and Eurostat show that human trafficking has a clear gender dimension. In fact they argue that the entire trafficking cycle is 
gendered from the root causes that make women and girls more vulnerable through to the policy approaches which are aimed at combating trafficking (see below).

\section{Gender, Sex Trafficking and Economic Globalization}

One of the reasons why gender plays such a significant part in sex trafficking is a result of the relationship between sex trafficking and economic globalization at both cultural and societal levels. This results in the vulnerability of women economically, in both underdeveloped and the developed world. This is captured by the work of Saskia Sassen $(2000,2001$, and 2002) in the development of the relationship between globalization and feminism. Goh (2009: 275) maintains that: "The gendered effects of globalization create the conditions in which women are disadvantaged economically and therefore vulnerable to being trafficked as sex slaves." Sassen (2000) examines what she calls a "global circuit" which involves traffickers and women as elements in the creation of profit emerging from the structural economic inequalities which globalization has created. Women's vulnerabilities whether poverty or migration put them in a position where they can be deceived, for example, where they may think they are going overseas to become factory workers or waitresses but instead they become sex workers.

A UNODC report in 2010 showed that commercial sex services in Europe are consumed almost exclusively by men and provided by women. The report also shows that around 1 million women in Europe could be involved in transactional sex. In addition the report also indicates that one in seven engaged in commercial sex is a trafficking victim which means a total of 140,000 victims, a market worth 2.5 billion Euros annually (United Nations Office on Drugs and Crime 2010). In addition other reports suggest that the proportion of trafficked women in prostitution is much higher (Huda 2006).

European states have adopted a variety of measures to reduce the demand for trafficking. Sweden, Norway and Iceland have adopted the "Nordic model" which punishes buyers of sexual services and at the same time decriminalising prostitutes. Sweden also prosecutes Swedish citizens who engage in sex tourism (Goh 2009). While most countries in the EU criminalise prostitution, some countries such as the Netherlands and Germany have legalised prostitution, so that they act as service providers (Wylie and McRedmond 2010: 99).

The main action coming from the EU on fighting trafficking in human beings is Directive 2011/36/EU which was adopted in 2011. This Directive goes further in adopting a victim-centred approach and apart from the prosecution of offenders, addresses prevention and support that must be gender 
specific. This is a huge step forward in recognising that women and men are trafficked for different reasons and that different forms of support are required. For example, we have already established that women are more likely to be trafficked to work in the commercial sex industry, whereas male trafficking victims are more likely to work in the mining, manufacturing, construction and agricultural industries (International Labour Office 2017). As such the needs of female victims may be different this shall be addressed later in the paper. Ultimately the focus of any rights based approaches emphasise "assistance and healthcare, labour rights, access to justice, legal defence and compensation" (Voronova and Radjenovic 2016:8).

Overall the EU has adopted an overview for the 2012-16 period which puts violence against women at the heart of trafficking. The EU has moved ahead on this policy with the appointment of an EU anti-trafficking coordinator who acts to improve the situation between EU institutions, EU agencies and Member States. The objective is to increase coherence between different bodies such as police, protection of human rights, migration issues and social and labour law. In contrast, in the ASEAN region Cheah (2006), writing from a human rights perspective, demonstrates how a criminal justice approach to sex trafficking has resulted in a failure to handle the issue effectively despite sex trafficking's historical and long-standing roots. She notes that: "The criminal law model focuses on penalization of the trafficking act and fails to adequately address the socio-economic causes and consequences of sex trafficking" (Cheah 2006:47). Cheah also points out that trafficked victims are not only from politically and economically marginalized classes but they also have to deal with the moral stigma of being sex workers. She notes that whilst there are an increasing number of males, especially young boys being trafficked for forced prostitution, the majority of sex-trafficking victims are women.

\section{Sex Trafficking and Tourism}

Carr (2016) identifies that to date there has been little examination of Sexual Tourism within tourist studies. Sexual tourism can be loosely defined as individuals planning travel around the purposes of obtaining sex (Blackburn et al 2011). Yeoman and Mars (2012) argue that throughout history there have been links between travel and sex; in their paper they present the case of Columbus' travels alongside the associated increased incidence of syphilis, arguing that the movement of men has historically been matched by an increased incidence of infections transmitted through sexual encounters. In contemporary society, sex is perceived as a mainstream entertainment product that is often packaged within the tourist industry as 'excitement' (Yeoman and Mars 2012; 367). 
As a result of this, Carolin et al (2015) highlights that almost every part of the world except Antarctica experiences sex tourism. Some of the key areas globally include: Netherlands and Thailand which are both sex tourism destinations for tourists from Australia, Europe, Japan and the United States. It has to be noted that the sex tourist industry is a substantial economy; for example in Thailand, it is estimated to be worth $\$ 25$ billion, equating to $12 \%$ of the country's gross domestic product (Forbes 1999), and as such is often promoted as part of national marketing strategies. However Carolin et al. (2015) cautions that whilst sex tourism exists throughout the globe, it consists of both legally run organisations as well as other businesses whose employees are sex trafficked. It is estimated that 250,000 Australian tourists visit Asia for sex with a minor each year, whilst 25 per cent of sex tourists come from the United States (Equality Now 2009). Men are more commonly sex tourists, with most being middle or upper class (Bender and Furman 2004).

Mullings (1999) makes the point that unlike ecotourism and heritage tourism, whose growth was linked to a flexible tourism strategy, sex tourism is viewed as a form of harassment that could potentially threaten the viability of the tourism industry as a whole. She argues that it is important that sex tourism is viewed as an export industry. In doing so the relationship can be cast as one where consumers import services from local providers.

\section{Vulnerability, Sex Trafficking and Sex Tourism}

There are other perspectives on the relationship between sex tourism and sex trafficking. As we have already identified, it is those who are the most vulnerable in society, often women, children, and individuals living in poverty that are most likely to be exposed to working in sex tourism or indeed experiencing sex trafficking. These individuals are identified as vulnerable, as a key facet of vulnerability is one's interaction with the social world (Author B). In that those who hold little power or status in the society in which they live, find themselves in positions of powerlessness and inferiority. They are perceived as having little intrinsic cultural worth or value and therefore become rendered as a commodity, to be sold in exchange for money, which is especially prevalent for women and children living in extreme poverty. This perception of them as a commodity can be further perpetuated when they enter the sex industry, either by choice or coercion as they can find themselves dehumanised, perceived as an object with little worth. This in turn, further increases their vulnerability, especially vulnerability to ill health.

There is a wealth of evidence that coercion into a sexual act both as an adult (Cary et al. 2016) and a child (Reid and Jones 2011) can have significant detrimental long term mental health consequences 
as well as increased likelihood of sexually transmitted infections (Matos et al. 2013). This increased health vulnerability is not matched by increased access to healthcare services; instead the opposite occurs in that individuals find it difficult to access healthcare, due to poor literacy skills, illegal immigrant status, language barriers, or that their traffickers attend the health services with them (Stanley et al. 2016; Hemmings et al. 2016).

There has been minimal research exploring the women who have been trafficked experiences of vulnerability, however one such study by Reed (2014) explored experiences of vulnerability of Filipino women trafficked into sex work. One of the key experiences identified in this research was the loss of identity. Many of the women reported losing themselves and who they were, they lost their names and identities and instead were given new names and identities or worst still, no name at all. They were perceived as having little intrinsic worth or value and therefore became nothing more than a sexual commodity. This feeling of dehumanisation was fuelled by a drug induced state, either as a mechanism of control by their traffickers, or for the women, a mechanism of escape from what was happening to them. Either way this leads to long term drug dependency alongside their poor mental health resulting in a negative spiral, as both drug addiction and poor mental health perpetuate the other.

Whilst it is at the individual personal level that the vulnerability is experienced, it is important to identify that this vulnerability is perpetuated at both a cultural and structural level (Author B). Vejar and Quach (2013) examined sex tourism in Thailand, identifying cultural facets which promote sexual slavery of women including religious texts which endorse prostitution as well as the established cultural history of sex working that commenced during the Vietnam War. At a structural level, the boosting sexual tourist industry in Thailand supports the Thai economy. It must be identified that the income associated with both sexual tourism and sexual trafficking is significant and this perpetuates the criminal activity, even to the extent that in some situations and circumstances powerful individuals turn a 'blind eye' at a structural level to what is occurring. So even though there are structural responses to tackling sex trafficking such as statutory agreed responses to collective action (United Nations Protocol to prevent, suppress and punish trafficking) which has an agreed action of supporting individual victims to recover through financial support or health access the research evidence identifies there is still much more work to be done.

The relationship between vulnerability and trauma in the context of sex tourism provides an interesting opportunity for an expansion of research in the tourism studies literature. While it is 
beyond the scope of this paper to address this field, one possible area of development would be the feminist ethics of care literature which might provide an opportunity for further interdisciplinary research and open up new policy areas for consideration. Some examples of this area include; Haker (2015), Hoglund (2003), Lowe (2015), Nussbaum (2006), Park and Herr (2017) and Robinson (1999). This would provide scope for a broader based theoretical framing of the issues and for a consideration of moral, ethical and social justice considerations. In addition, this would also provide a useful platform for a fuller consideration of the implications of the issue of sex tourism in relation to the implications for physical and emotional health. The ethical and moral implications for the tourist industry and for expanding the field of tourism literature and research are addressed below.

\section{Tourism's Response to Sex Trafficking and Sex Tourism}

In terms of a moral and ethical responsibility the tourism and hospitality industry has a social responsibility to counteract trafficking. The United Nations (2012) has stressed the need for the tourism and hospitality industry to help with putting a stop to sex trafficking. In response to this the industry has developed a Tourism Child-Protection code of conduct for dealing with the sexual trafficking of children (ECPAT 2017). By 2013, there were 1,287 signatories with 140,096 trained staff in 52 countries (Mohn 2012), and by 2017 this had grown to 303 members, 401,625 trained staff in 206 countries (The Code 2017). By signing up to this Code travel organisations commit to six essential steps to protect children:

1. Establish a policy and procedures to protect children against sexual exploitation

2. Train their employers in children rights, and reporting mechanisms

3. Include a clause in contracts stating a zero tolerance policy of sexual exploitation of children

4. Provide information to travellers on children rights, prevention of exploitation and reporting mechanisms

5. Support collaborators and engage stakeholders

6. Report annually on their implementation of the code.

Whilst the Code is an excellent initiative to address childhood sexual exploitation, it is only voluntary set of business principles that travel and tour companies can implement to prevent sex tourism and trafficking of children, as such it has little power to enforce change. As such we argue that the industry has to do more to address the sexual exploitation of children, such as making this code mandatory. In addition, the Code only attempts to address sexual exploitation of young people up to the age of eighteen. Yet we argue that any individual who is at risk of trafficking for sexual exploitation is no less vulnerable one day before or one day after their eighteenth birthday. Whilst 
we do not wish to diminish the importance of this initiative, we wish question whether there should be a counterpart to protect vulnerable women from sexual exploitation. The fact that currently no such initiatives exist highlights and reasserts to us the worldwide cultural perceptions of the negative value of women in society and reflects the gender inequality that occurs. As well as highlighting the power of the global sex industry, which contribute a significant proportion of countries' economies and as such, is against the national interest to put strategies in place to restrict the industry.

There are however a range of programs run by the transportation industry particularly the airlines to educate the airline staff and flight crews as regards indicators of human trafficking (Beauchamp 2014). The difficulty with sex trafficking is that is a largely a closed, hidden industry that is not openly discussed or debated. Instead, it is a topic which makes people feel very uncomfortable as it reminds us of the darker side of our human nature. Yet by not having these debates then we are silently complicit in accepting both sexual tourism and sexual trafficking and as a by-product of that perpetuating the vulnerability and abuse of those who are caught up in this industry. Instead we position that it is important for both the tourist industry as well as practitioners working in the industry acknowledge and accept that this practice occurs. Once we do this, then we can begin to start having conversations and debates both within the tourism profession but more importantly with other professional groups and shine a light on these dark issues.

\section{Contribution of Intersecting Perspectives to an Understanding of Sex Tourism within Tourism Studies}

Throughout this paper the authors have adopted an inter and multi-disciplinary approach through the literature on sex trafficking and sex tourism drawn upon in order to expand an understanding of tourism studies in terms of moral and ethical considerations. To date, sex trafficking has not been a major focus of tourism studies hitherto, because the issues of human rights within tourism have not been a major focus of the field of tourism studies. Yet sex trafficking and sex tourism are both fields that would benefit enormously from an analysis of the relationship between tourism and human rights. The literature and approach offered here sheds a set of new and different perspective on the field. In addition, the paper also considers the implications for policy development in relation to governmental policy in different areas and the implications for tourism studies. This allows for a more specific regional focus which comes from an analysis of governmental policy and tourism whilst allowing for regional variations in terms of responses. Tourism studies cannot operate in a 
moral and ethical vacuum and requires a broad based understanding of the implications of aspects of fields of study that fall within its discipline, including sex trafficking and sex tourism.

\section{Conclusion}

The paper has explored the relationship between sex trafficking, gender and migration and considered how sex tourism has developed from this relationship. Furthermore, the paper has considered social and theoretical aspects of vulnerability that emerge from sexual trafficking, at a personal as well as cultural and societal level. A range of perspectives drawing on a wide range of relevant contemporary literature has been examined including socio-economic, human rights, feminist, migration, health perspectives as well as tourism perspectives. The presenting of these often contesting perspectives provides a more comprehensive understanding of the interconnecting relationship of sex trafficking and sex tourism. In doing so, this paper opens and contributes to the debates regarding the wider implications of sexual trafficking in the global sex industry.

The question of whether it is the responsibility of the tourism industry or responsibilities of specific governments to deal with sex tourism and sex trafficking requires further debate. The issue is one which we feel requires a combined response, as such this paper provides a framework for future research and policy development enabling an in-depth exploration of the intersection of sex trafficking and tourism. Globally, the relationship between sex trafficking and sex tourism needs further investigation in light of the significant implications not only on the tourism industry but also the individuals concerned.

\section{References}

Augustin, L. (2005) “Migrants in the Mistress's House: Other Voices in the 'Trafficking Debate'”, Social Politics, 12: 96-117

Augustin, L. (2006) "The Disappearing of a Migration Category: Migrants who Sell Sex", Journal of Ethnic and Migration Studies 32(1): 29-47

Augustin, L. (2008) Sex at the Margins, Migration, Labour Markets and the Rescue Industry, London:

Zed Brooks

Bender, K and Furman, R. (2004) “The Implications of Sex Tourism on Men's Social, Psychological and Physical Health", The Qualitative Report Vol 9, pp.176-191

Blackburn, A., Taylor, R., \& Davis, J. (2011). Understanding the Complexities of Human Trafficking and Child Sexual Exploitation: The Case of Southeast Asia. In F. Bernat (Ed.), Human sex trafficking (pp. 104-125). London: Routledge. 
Blanchet, T. (2002) Beyond Boundaries: A Critical Look at Women, Labour, Migration and the Trafficking Within. Dhaka: US Aid

Carolin, L., Lindsay, A. and Victor, W. (2015) "Sex Trafficking in the Tourism Industry", Tourism and Hospitality, Vol 4 No 4, pp. 1-6

Cary, M, Oram, S, Howard, L, Trevillion, K and Byford, S (2016) "Human trafficking and sever mental illness: an economic analysis of survivors' use of psychiatric services", BMC Health Services Research, 16 pp.1-8

Cheah, Wuiling (2006) "Assessing Criminal Justice and Human Rights Models in the Fight Against Sex Trafficking: A Case Study of the ASEAN Region" Essex Human Rights Review 3 (1) pp. 46-63 Doezema, J. (2010) Sex Slaves and Discourse Masters: The Construction of Trafficking. London/New York: Zed Books

ECPAT (2017) The Tourism Child-Protection Code of Conduct. Available at http://ecpatusa.org/code/ [accessed 2 June 2017]

Equality Now (2009) United States: Sex Tourism; Big Apple Oriental Tours Acquitted of State Criminal Charges. Federal Action Needed to Prosecute G. F Tours and Other US based Sex Tour Operators. Available from https://www.equalitynow.org/action-alerts/sex-tourism-big-apple-oriental-toursacquitted-state-criminal-charges-federal-action [accessed 19.3.2018]

European Commission (2012) The EU Strategy towards the Eradication of Trafficking in Human Beings 2012-2016. Available at: http://ec.europa.eu/anti-trafficking/publications/e-book-eustrategy-towards-eradication-trafficking-human-beings-2012-2016 en [Accessed 19.3.2018]

European Court of Auditors (2017) EU support to fight human trafficking in South/South-East Asia Luxembourg: European Court of Auditors Forbes (1999) GDP the Sex Sector, Available from: https://www.forbes.com/forbes/1999/0614/6312214s2.html\#d82b2c12cc7b [accessed 19.3.2018]

Goh, Janice Phaik Lin (2009) “Deterritorialized Women in the Global City: An Analysis of Sex Trafficking in Dubai, Tokyo and New York", Intersections, Vol 10 No. 2, pp. 271-824 Haker, H. (2015) "Catholic Feminist Ethics Reconsidered: The Case of Sex Trafficking”, Journal of Religious Ethics', 43(2): 218-243

Heaslip, V, Hean, S., Parker, J, (2016) "The etemic model of Gypsy Roma Traveller community vulnerability: is it time to rethink our understanding of vulnerability? Journal of Clinical Nursing, (in press)

Hemmings. S, Jakobowitz, S, Abas, M, Bick, D, Howard, L.M, Stanley, N, Zimmerman, C and Oran, S (2016) "Responding to the health needs of survivors of human trafficking: a systematic review, $B M C$ 
Health Services Research, Vol 16 No 320; pp. 1-9

Hoglund, A.T. (2003) "Justice for Women in War Feminist Ethics and Human Rights for Women", Feminist Theory 11(3): 346-361

Huda, S. (2006) "Sex Trafficking in South Asia" Gynaecology and Obstetrics, 94: 374-381

Human Rights First (2017) Fact Sheet Human Trafficking by the Numbers; available from https://www.humanrightsfirst.org/resource/human-trafficking-numbers [Accessed 18.3.18] International Labour Office (2017) Global estimates of modern slavery: Forced labour and forced marriage. Geneva: International Labour Office

Kempadoo, K. (1999) Sun, Sex and Gold: Tourism and Sex Work in the Caribbean. Lanham: Rowan and Littlefield

Kempadoo, K. with J. Sanghera and B. Pattanaik (eds) (2005) Trafficking and Prostitution Reconsidered: New Perspectives on Migration, Sex Work and Human Rights. Boulder and London:

Paradigm

Lim, Lap-Chew and Wijers, Marian (1997) Trafficking in Women, Forced Labour and Slavery-like Practices in Marriage, Domestic Labour and Prostitution (Utrecht: Foundation Against Trafficking in Women [STV] and Bangkok: Global Alliance Against Traffic in Women [GAATW] Lowe, L. (2015) The Intimacies of Four Continents. Durham, N.C.: Duke University Press Matos, M, Caetano, K., Franca, D., Pinheiro, R., Moraes, L., and Teles, S (2013) "Vulnerability to sexually transmitted infections in women who see sex on the route of prostitution and sex tourism in Central Brazil, Rev.Latino-Am. Enfermagem, Vol 21 No 4, pp. 906-12

Mohn, T. (2012) The Travel Industry takes on Human Trafficking, The New York Times Nov 8, 2012 http://www.nytimes.com/2012/11/09/giving/the-travel-industry-takes-on-human-trafficking.html Mullings, B. (1999) "Globalization, Tourism and the International Sex Trade". In K. Kempadoo (eds) Sun, Sex and Gold: Tourism and Sex Work in the Caribbean. Maryland/Oxford: Rowan and Littlefield Murray, A. (1998) "Slavery and Trafficking: Don't Believe the Hype". In Global Sex Workers: Rights, Resistance and Redefinition. New York: Routledge.

Nussbaum, M. (2006) "Whether from Reason or Prejudice. Taking Money for Bodily Services," see Spectator 2006, 175-208

Park, S. and Herr, R. S. (2017) "Introduction: Contested Feminisms" Hypatia, 32 (3) (Summer 2017) Pearson, E. (2002) Human Traffic Human Rights: Redefining Victim Protection. London: Anti-Slavery International

Reed, A. (2014) Exploiting Vulnerability: A Study of the Lives of Filipino Women who have been Trafficked into Sex Work. Unpublished Master's Thesis. RMIT, Melbourne, Australia. 
Reid, J. A. (2012) "Exploratory Review of Route-Specific, Gendered and Age-Graded Dynamics of Exploration. Applying Life Course Theory of Globalisation in Sex Trafficking in North America",

Aggression and Violent Behaviour, Vol 17, pp. 257-271

Reid, J.A. and Jones, S (2011) "Exploited Vulnerability: Legal and Psychological Perspectives on Child Sex Trafficking Victims", Victims and Offenders, Vol6, pp.207-231.

Robinson, F. (1999) Globalizing Care: Ethics, Feminist Theory and International Relations. (Boulder, CO: Westview Press)

Sassen, Saskia (2000) “Women's Burden: Counter Geographies of Globalization: The Feminization of Survival", Journal of International Affairs, Vol 53, pp.503-524

Sassen, Saskia (2001) The Global City. Princeton: Princeton University Press

Sassen, Saskia (2002) "Global Cities and Survival Circuits" in Global Woman: Nannies, Maids and Sex Workers in the New Economy eds. Barbara Ehrenreich and Arlie Hochschild (New York: Henry Holt and Company) pp.254-274

Secretary of State, (2012) Council of Europe Convention on Action against Trafficking in Human Beings. Stationery Office, London.

Stanley, N, Oram, S, Jakobowitz, S, Westwood, J, Borschman, R, Zimmerman, C, Howard, L, (2016)

"The health needs and healthcare experiences of young people trafficked into the UK", Child Abuse \& Neglect, Vol 59, pp.100-110.

The Code (2017) "The Code of Conduct for the Protection of Children from Sexual Exploitation in Travel and Tourism", available at: 2 February http://www.thecode.org (accessed 2 February 2017) United Nations Office on Drugs and Crime (2016) Factsheet on Human Trafficking. United Nations Office on Drugs and Crime, available from https://www.unodc.org/documents/humantrafficking/UNVTF fs HT EN.pdf [accessed 19.3.2018]

United Nations Office on Drugs and Crime (2010) The Globalization of Crime; A Transnational Organized Crime Threat Assessment. Vienna: United Nations Office on Drugs and Crime

United Nations Office on Drugs and Crime (2009) Global Report on Trafficking in Persons. Vienna: United Nations Office on Drugs and Crime

United Nations (2012) Global Initiative to Fight Human Trafficking, NODC, UNWTO stress need for Tourism Industry Cooperation in Combating Human Trafficking. 21 Session of the Commission on Crime Prevention and Criminal Justice, Vienna.

United Nations (2000) Protocol to prevent, suppress and punish trafficking in persons, especially women and children, supplementing the United Nations convention against transnational organized Crime. General Assembly resolution 55/25. New York, NY, United Nations General Assembly, 2000. United Nations Office on Drugs and Crime (2010) Annual Report 2010. Vienna: UNODC 
https://www.unodc.org/documents/AnnualReport2015/Annual_Report_2016_WEB.pdf (Available 5 June 2017).

US Department of State (2006) Trafficking in Persons Report. Office to Monitor and Combat Trafficking in Persons. Washington DC: US Department of State

US Department of State (2012) US Department of State Foreign Affairs Manual, Volume 9 Visas. (Washington DC: US Department of State)

Vejar, C.M. and Quach, A.S (2013) "Sex Slavery in Thailand", International Consortium for

Social Development, Vol 35, No2, pp. 105-123.

Voronova, S. and Radjenovic, A. (2016) The Gender Dimension of Human Trafficking. European Parliamentary Research Service Briefing, February 2016: 1-10

Wylie G, and McRedmond, (2010) Human Trafficking in Europe: Character, Courses and Consequences. Basingstoke: Palgrave/Macmillan.

Yeoman I, and Mars M (2012) Robots, men and sex tourism, Futures 44, pp. 365-371 